\title{
Beauty in the eye of the design reviewer: The contested nature of UK design review
}

DOI:

10.1080/13574809.2018.1511973

\section{Document Version}

Accepted author manuscript

Link to publication record in Manchester Research Explorer

\section{Citation for published version (APA):}

Black, P. (2018). Beauty in the eye of the design reviewer: The contested nature of UK design review. Journal of Urban Design, 24(4), 556-574. https://doi.org/10.1080/13574809.2018.1511973

\section{Published in:}

Journal of Urban Design

\section{Citing this paper}

Please note that where the full-text provided on Manchester Research Explorer is the Author Accepted Manuscript or Proof version this may differ from the final Published version. If citing, it is advised that you check and use the publisher's definitive version.

\section{General rights}

Copyright and moral rights for the publications made accessible in the Research Explorer are retained by the authors and/or other copyright owners and it is a condition of accessing publications that users recognise and abide by the legal requirements associated with these rights.

\section{Takedown policy}

If you believe that this document breaches copyright please refer to the University of Manchester's Takedown Procedures [http://man.ac.uk/04Y6Bo] or contact uml.scholarlycommunications@manchester.ac.uk providing relevant details, so we can investigate your claim.

\section{OPEN ACCESS}




\title{
Beauty in the eye of the design reviewer: The contested nature of UK design review
}

\author{
Abstract \\ Design review is an independent expert-led mechanism, employed to evaluate the \\ design quality of proposed developments. It claims an objective and transparent \\ approach, yet has limited guidance on how, or what, reviewers should evaluate. \\ Few studies focus on these reviewers or their attitudes and perceptions to the \\ process. This research, using interviews and Q-Methodology, reveals key \\ differences in how reviewers conceptualise and evaluate design quality within \\ review. The paper argues design review is a contested mechanism, where \\ subjective appraisal plays out alongside more objective approaches. Four \\ competing reviewer priorities on the process are presented: sustainability; \\ people/public; function; and visual aesthetics.
}

Keywords: design review; design; agency; quality

\section{Introduction}

The use of design review in the UK has a long and complex history (Higgins and Karski 2000). It is now recognised as a crucial part of the development management system and the drive towards increasing the quality of design in the built environment (DCLG 2012). Therefore, whilst the central player in the process of design control remains local planning authorities, and the planners they employ (with political oversight) (Dawson and Higgins 2009), the emergence of the design review panel has added a different and new dimension (Carmona and Sieh 2004). Design review claims to be objective, impartial, independent, and transparent in how it evaluates design quality in the UK (Design Council CABE 2013), yet questions remain as to how accurate these claims might be when considering the process of review, and its remit in judging design quality. A number of prominent studies and reports have recently called 
for design reviews remit to be extended and integrated better into the planning process (e.g., Farrell 2014). However, the mechanism suffers from criticisms that it lacks transparency (Place Alliance 2018), accountability and detail (Lock 2009), whilst Professor Matthew Carmona in his 2016 blog 'Design review: past, present and future' argues it requires more evidence of its effectiveness.

Design reviewers are faced with a myriad of factors to consider when evaluating a proposal, Carmona (1998) listed Intervention vs. interference; process or product; objectivity vs. subjectivity; urban vs. architectural design; democracy vs. individual rights; the role of the professional; interpreting design; innovation in design. These factors hint at a contested arena, an arena wherein the agency of individuals is key. To date previous studies on design review have not solely focused on the reviewer's attitudes and perceptions of its purpose and process. This paper, using in-depth interviews and Q-Methodology, engages directly with reviewers on the subjects of design quality and the review process, to illuminate the hidden, or 'veiled', elements, providing a picture of a mechanism without a clear methodology.

\section{Design Review in the UK}

The control of design in the UK falls under the wider regulatory structure referred to as 'development management'. The history of design control can broadly be viewed as an evolution from elevational control, through aesthetic control, to urban design control and quality place making (Punter 2010). All attempts by government to regulate design sit within this framework, which is more than simply an administrative process; rather it should be understood as a multifarious negotiating process between stakeholders (Davies 1980). A distinguishing feature of a planning system is often the instruments that are utilised to consider design quality, the design specific elements of 
planning controls (Carmona and Sieh 2004). Independent design review panels are a core instrument available to local planning authorities in the UK, providing expert-led impartial design evaluation and judgments, to act as

"An independent and impartial evaluation process in which a panel of experts on the built environment assess the design of a proposal" (Design Council CABE 2013).

Design review's history can be traced as far back as 1802 in England, with the formation of the Royal Fine Arts Commission in 1924 the most prominent and successful exponent of the discipline until its demise in 1999 (Carmona 2016a). Contemporary design review, embedded across the UK, was predominantly shaped by the emergence of the Commission for Architecture and the Built Environment (CABE), founded in 1999. CABE was established by the government to help implement better quality design (Punter 2010), and established a national design review panel that reviewed a wide variety of schemes including regeneration, public, transport and infrastructure, retail, office, sport, heritage, residential, cultural, tall building, and master planning (Carmona et al 2017). CABE lost its central funding in 2011 and its design review service was ported to Design Council CABE, which commercialised the product, charging clients for the process (Hopkirk 2012)

CABE's legacy of promoting and guiding design review panels remains evident throughout the UK today, with an exponential increase in recent years seeing almost $100 \%$ of local authorities in England having access to a panel at local, sub-regional, or regional level (CABE, 2009). Regional panels are coordinated through the Design Network, set up in 2013 to host 8 regional design review panels, and despite early problems this network is currently operating successfully with solid coverage for all of England in respect to design review (Carmona et al 2017). National panels in Wales 
(Design Commission for Wales); Scotland (Architecture and Design Scotland); and Northern Ireland (Ministerial Advisory Group), have all replicated the CABE model for design review. Design review is now an essential part of the planning process (Design Council CABE 2013) and the publication of the National Planning Policy Framework (DCLG 2012) reinforced its role in promoting and achieving high quality design standards. The UKs contemporary design review is the most international referenced process, including governments and governance bodies in USA, Canada, and Australia (Hassell 2011), illustrating its reach and influence.

Design review panels have no legal basis for their existence, although have been endorsed by central government in numerous guidance manuals (e.g. CABE 2002 and 2006). Local planning authorities that utilise the process are under no statutory obligation to heed a panels recommendations or advice when considering design proposals (DCLG 2014). Whilst the NPPF does promote the use of review, there have been calls for this to be strengthened (Bishop 2011). Others suggest review should be made mandatory for all publically funded commissions (Farrell 2014) and all major planning applications (House of Lords, 2016), with the Mayor of London arguing in 'Good Growth By Design' that all major schemes as part of the London Plan should be subject to the process to improve design quality.

The panels are made up of independent experts drawn from a wide range of professions (DTLR 2000), with this multi-disciplinary nature a core principle underpinning the mechanism. Whilst the mandate for review is clear, to evaluate proposed design or placemaking for quality (Place Alliance 2018), the process for these evaluations and the attitudes and actions of reviewers are less clear. Below the Design Network, for example, other design review panels operate without a core regulator, resulting in a variety in quality and approach (Carmona et al 2017), with Urban Design 
London (2015) arguing current design review requires much more “coordination, clarity and consistency" (p9).

Statements of procedures and working methods have been consistently published by CABE (CABE 2002 and updated 2006) and later re-published by Design Council CABE with Landscape Institute, RTPI, and RIBA (see Design Council CABE [2013]) and Transport for London with Urban Design London (TfL 2013). These principles of review are an attempt to make the process more systematic and transparent, adding a level of clarity by claiming review to be independent; expert; multidisciplinary; accountable; transparent; proportionate; timely; objective; and accessible. There is also best practice guidance on how design review might achieve better outcomes in an efficient and equitable manner (Punter 2010; CABE 2009). However review has remained open to accusations it lacks transparency and needs to be more accessible (Place Alliance 2018).

\section{The Contradictions of Design Review}

The concept of 'design' offers a range of challenges for any regulatory system of governance, such as design review. A simultaneously creative and emotive discipline, design is a difficult thing to regulate objectively or consistently (Carmona 2014) often leading to policy or approaches that are regarded as highly discretionary and flexible (Carmona et al 2017). This can make regulatory outcomes difficult to predict, as approaches taken by agents of these processes can vary. Such discretion and agency in the process arguably contradicts some of the claims of independence, impartiality, objectivity, accessibility, and transparency that design review promotes. These procedural ambitions are challenged by two fundamental questions facing review What is being reviewed, and how? And who is review for? 


\section{What is being reviewed?}

There are a number of suggested issues that design reviewers can consider in the review process; sustainability (Punter and Carmona 1997); promoting community growth (Schiffman 1989); encouraging designers to not comprise on quality (Dawson and Higgins 2009); reflecting public attitudes (Stamps 2000); plus a series of 'objective' issues including access, safety, health, comfort, vitality, and sociability (Punter 2006) and materials, mixed uses, and the relationship of buildings to space (Delafons 1994). Dawson and Higgins (2009) argue that review must eschew personal subjective preferences to avoid being discredited and rendered ineffective, however two significant issues contradict this claim of objectivity.

First, Carmona (2009) argues that it is an impossibility for legislation to solely deliver design quality, with high quality architecture, and place, difficult to define or even recognise, indicating the difficult task review panels face in evaluating quality. Whilst some argue everything in design can be the subject of rational enquiry (Schumacher 2011), it remains that quality is an arguable concept, open to a wide range of interpretations (Rönn 2011). Carmona (2016b) argues it will mean different things to different people. Previous research into individuals understanding or perception of design quality has illustrated the spectrum of attitudes with regards how 'quality' is defined and viewed in design or place making (Devlin 1990; Hubbard 1996; Gillford et al 2000). Conway and Roenisch (2005) recognise the difficulty in assessing design in a purely objective manner and promote a system not devoid of subjective elements, but rather balancing the subjective and objective.

Second, the guidance of national panels such as A+DS (Scotland) (SE 2005) and MAG (Northern Ireland) (DCAL 2006) utilise terms that remain vague, suggesting 
professional expertise and experience is required in interpreting, or passing judgment, on these matters. Terms such as 'desirable', 'harmonious', 'consistent'. 'appropriate', 'proportional', 'context', and even 'quality' are synonymous with design review (Hindshaw 1995), yet remain subjective by nature. Case Scheer (1994) argues this is the natural order of things and design review should embrace this subjective as no universal objective standard exists from which to make judgments, that freedom is a necessity in order to allow places to surprise and delight. Issues arise due to the contemporary claim of objectivity and transparency in design review. Part of this is a purposeful distancing from the more 'traditional' approach of it predecessor the Royal Fine Arts Commission, due to the 'cloak of diplomacy and secrecy' under which it operated and which often surrounded its interventions (Punter 1984). There is also the desire for legitimacy as a process; Carmona (2016a) asks pertinent questions regarding the value of the process and how accountable and transparent it is in practice. It remains unclear in UK design review which approach reviewers themselves champion, the contested negotiated approach that balances objective with subjective, or a transparent agenda wherein subjective perspectives are shunned in favour of exclusively objective evaluations?

\section{Who is Review For?}

Some apposite questions that must be tackled in any evaluation of design is what is being judged? Whose judgments actually matter? And in whose interests is it to control or evaluate the quality of physical design in architecture? (Case Scheer 1994). To ensure the role and process of design review is transparent and impartial, these are vital questions for contemporary design review panels.

\footnotetext{
"The question as to whose aesthetic is being promoted in control is one that should be continually asked by design policymakers and controllers to keep themselves
} 
honest, to remember that they are supposed to represent the public interest in the development process.” (Punter 1999 p97).

Fundamentally design review raises questions of power, over whose agenda is to be promoted, pursued, and implemented, and what that agenda looks like. Design Council CABE (2013) argue that review "offers expert views that take account of a wide range of complex issues", yet design reviewers views have the potential to differ from one another, and if such differences occur the reviewer would be left to decide if he or she should subordinate personal judgement to the views of others (Stamps 2000). The lack of clear prescription in the current review process potentially provides a platform for individual reviewers to make decisions and pass judgments beyond any agreed set of principles (either official or understood) or accepted standards. Ultimately the design review chair plays a significant role, as they are responsible for making sense of the myriad of comments and assessments, with the success of review arguably linked directly to the quality of this chairperson (Carmona et al 2017).

Place Alliance (2018) highlight that design review can have benefits for society, designers, applicants, and local authorities, but in whose interests are the panels assessing design quality? It may be possible for reviewers to act as representatives of wider society (Stamps 2000), yet their remit must be broader than this if review is to be truly independent. With no clear answer, reviewers have potential freedoms within the process to shape evaluations and even outcomes through high levels of inherent discretion and individual agency. This paper argues it is therefore imperative for studies of design review to engage with this agency, not simply the structures, to truly understand the process and purpose of review in practice. 


\section{The Agency of Reviewers}

"It is instinctively clear that different stakeholders are likely to have very different motivations and perceptions as regards the built environment" (Carmona et al 2002 p147).

Design review as a instrument of design management is not exclusively responsible for how the built environment will be shaped, the decision making process is a complex one with many actors, including architects, clients, the public and politicians. Yet as design review becomes more embedded within the wider design management system in the UK, its responsibility grows and the role of these panels, and the 'independent' individuals (agents) who sit on them, must come under deeper scrutiny.

Dear and Moos (1986) place the notion of governmental or institutional action as meaningless unless it is understood that it is the individuals within the structure that act. Contentious interaction between structure and agency in the realm of design control helps to explain why the production of the built environment varies from place to place and from one year to the next. With such a broad range of stakeholders involved in making, using and managing urban development it can be seen that each has different reasons for investing in good design; some will have short term expectations, others will base their approach on long term results. Design review relies rather on an 'expert-led' approach to quality assessment, within a structured framework. To fully understand its role, approach, and impact it is necessary to understand how these 'expert' reviewers operate in practice. Design review may promote itself as undertaking a 'technocratic postmodernist' approach (Onaran and Sancur 1998), seeking ways to define standards, employing objectivist reasoning, and relying heavily on expert judgement in formulating regulations or recommendations. This paper suggests that whilst design 
review promotes this rhetoric, in reality the very nature of evaluating design quality in this way leads to issues of power, taste and diversity in approach.

\section{The Attitudes and Perceptions of Reviewers (Methods)}

A post-positivist typology views design reviewers as imperfect advisors who operate in a complex system, in which there are no answers, only 'options'. The emphasis is therefore on 'making meaning' through language, as planning structures can be characterised as fragmented, plural, subjective, and open to interpretation (Allmendinger 2002). These individuals, whilst not completely autonomous agents due to their operating within a framework that includes limitations, can be classified as imperfect people whose judgments can lead to imperfect regulation (Hansen 2006). For this reason this paper recognises the need to engage directly with design reviewers, they have significant 'power' in shaping and defining design review as a process and tool for shaping change and quality in the built environment. Through exploring their attitudes and perceptions, one can begin to understand the role of subjectivity in the process, yet the methodology must be robust enough to go beyond casual reasoning to discovering and confirming meaning.

Q-Methodology has been employed on this research to provide a foundation for the systematic study of design reviewer's viewpoints, opinions, perceptions, and attitudes (Van Exel and de Graaf 2005). Q-Method is designed to ascertain how individuals think about a particular subject matter, identifying those with common views on a specific topic, including the perspectives that decision makers bring to policy issues (Brown et al 1998). Q-Methodology combines qualitative study of attitudes with the statistical rigour or quantitative research techniques (McKeown and Thomas 1988). Table 1 provides a step-by-step guide as to how Q was applied on this 
study. The result of this process is the identification of a series of distinctive factors, or discourses, reflecting clusters of participants (design reviewers) that share a similar view (Ellis et al 2007). Design reviewers undertook two separate Q-sorts (see Table 1) exploring their attitudes and perceptions on (1) defining design quality in the context of design review; (2) the operation, process, and role of design review. This study explored both retired and active members from the national design review panels of Scotland (Architecture and Design Scotland (A+DS)) and Northern Ireland (Ministerial Advisory Group (MAG)).

Table 1. Application of Q-Methodology in design review - 5 Steps.

Figure 1. Ranking format grid Q-Methodology: Reviewers Q-Sort on purpose and process of design review.

\section{Defining Design Quality in Design Review}

Upon completion of step 1 (see Table 1), a final list of 23 statements was identified (Table 2) covering a broad range of issues regarding reviewers attempts to articulate the key components for defining design quality within design review. Following the Q-Sorting, 3 distinct discourses were identified that showcase different philosophies of design quality. Each has been given a title to reflect the main characteristics defining the discourse, and they are briefly described below. The discourses are: The Sustainable Functionalist; The Architects Disciple; and The Contextual Populist.

Table 2. Design quality Q-Sort statements and discourse rankings. 


\section{A. THE SUSTAINABLE FUNCTIONALIST}

Explains 24\% of the study variance.

The distinguishing features of this discourse link design quality most directly to sustainability (Statement 16 / Ranking +1$)$, functionality $(2 /+3)$, and quality of materials utilised $(1 /+3)$. Quality here is presented as striking $(13 /+2)$, but this is defined as beyond the subjective assessment of aesthetics or beauty $(5 /-1)(6 /-3)$. Striking design quality is rather identified as

\footnotetext{
"Getting right the things you can influence, you can ensure your materials are well chosen and sustainable, and you can make the building work inside and out in terms of flow and movement and ease of access" (Reviewer 9).
}

This discourse hints that achieving this aim is about more than the skill of the architect alone $(12 /-2)$.

\section{B. THE ARCHITECTS DISCIPLE}

Explains $17 \%$ of the study variance.

The distinguishing features of this discourse are that key stakeholders, predominantly the architect $(12 /+3)(18 /+2)$, but also the support of the client $(17 /$ +2 ), play the most significant role in achieving design quality.

\footnotetext{
"It is the architect who designs, who makes the decisions that will result in quality or mediocrity... [they] will be the hero or die by [their] own sword, not all are up to the task" (Reviewer 13).
} 
The skill of the architect is about more than the ability to design aesthetically pleasing places and buildings $(5 /-2)$. It is rather about producing environments that evoke a range of senses $(20 /+3)$ through use of materials, functionality, and being contextually responsive.

\section{THE CONTEXTUAL POPULIST \\ Explains $20 \%$ of the study variance.}

The distinguishing features of this discourse link design quality most directly to contextually responsive design $(21 /+3)$; simplicity in the designers approach $(14 /+3)$; and the attitudes of the public being valued and considered in defining quality $(8 /+2)$. This discourse also agues that any evaluation of quality must include both objective and subjective $(13 /+2)$, acknowledging that personal tastes will undoubtedly place a role in deciphering quality $(10 /-3)$.

"The public have a role in deciding what is important in design, this invites personal preference in, as reviewers we have to then balance this with strong accepted criteria testing" (Reviewer 3 ).

\section{The Quality Debate}

The three identified discourses provide a number of interesting insights, in particular regarding what factors define quality within the built environment, and whose value judgements have priority in both the creation of, and evaluation of quality. There is a clear agreement across the discourses that to identify quality a balance between personal tastes (subjectivity) and objectivity is required. This balance in many ways reflects the 
current UK design control system, a discretionary model that includes both structured policy and guidance, but also in-built flexibility ensuring high levels of agency in the evaluation or decision making process. The acceptance of some subjectivity in the evaluation of design quality within design review has consequences for the review process, especially considering the three discourses above illuminate very different attitudes (personal perspectives) as to the key variables necessary in the pursuit of design quality.

On of the most prominent areas of contention identified centres on the link between sustainability and quality. The Sustainable Functionalist champion's sustainable design approaches as key to defining the 'quality' of any proposed design scheme, yet The Architects Disciple argues that the absence of traditional sustainable elements does not necessarily have a negative impact on whether a scheme can be deemed of high quality. Indeed the discourses each display a varying range of features and influences that reviewers believe impact upon design quality, concerns such as sensory experiences, materials, context, and even simplicity of vision and execution. This variety on display points to the complexity inherent in reviewing design, and strengthens the demand for further research into the process of the review mechanism in practice.

Perhaps the most striking area of contention across the three discourses, given away in the discourse titles, is the priority given to different key stakeholders in the production of, and evaluation of, design quality. The role and importance of architect, the client, and the public are significant points of disagreement. The Architects Disciple proposes the architect, and their skill level, as a core component in the delivery of quality design projects. This discourse also promotes the role of the client, an opinion at odds with the attitudes displayed in the other two discourses. The Contextual Populist 
meanwhile champions the role of the public in conceptualising quality, again contrasting dramatically with other discourse findings. Empowering the attitudes, or contribution, of others as key in exploring quality further complicates evaluation through objective means only, and it is important to consider how these views may be considered in the actual process of design review.

These three discourses have illustrated the differences in how design reviewers think about and discuss the issue of design quality in general terms, yet say little as to how the mechanism of review operates in regards to evaluating quality in an official capacity. Questions remain as to the agency afforded these reviewers to promote their particular understanding of what constitutes quality and how it should be assessed. The second Q-Sort conducted within this research focuses specially on evidencing the range of perceptions on how the review process operates in real-world scenarios, ascertaining if these differences in discussing design quality play out in review proper and how.

\section{Design Review: Purpose and Process}

The second Q-Sort was based on design reviewer's perceptions on the purpose and process of review. 34 statements were sorted (Table 3 ) and 4 distinct discourses identified, The Objective Contextualist; The Beauty Hunter; The Democratic Proceduralist; and The Critical Functionalist. Each discourse is described in detail below, each represents a unique way in which $\mathrm{h}$ reviewers think about, and evaluate within, the review process.

Table 3. Design review purpose and process Q-Sort Statements and discourse rankings. 


\section{THE OBJECTIVE CONTEXTUALIST}

Explains $26 \%$ of the study variance.

The distinguishing features of this discourse are that design review adopts a holistic approach to assessing and understanding design $(13 /+4)$. This approach is defined by accepted standards through which panels can assess $(18 /+3)$ on issues such as sustainability $(12 /+4)$ and contextual responsiveness $(8 /+3)$. There is some acceptance that aesthetics can play a role in design evaluations, but

\footnotetext{
"Taste and personal conjecture are a matter for the school yard, not the national design review panel of carefully chosen professionals from across the breadth of the country, it is not about what we like, but what works, what works best, and what will be the most suitable design solution for all involved" (Reviewer 14).
}

Reviewers most closely associated with this discourse also point towards the importance of considering community views on design quality in the review process ( 7 / $+3)(32 /+2)$.

\section{E. THE BEAUTY HUNTER}

\section{Explains $11 \%$ of the study variance.}

The distinguishing features of this discourse are the clear links between design review evaluations and visual aesthesis $(4 /+4)$, defining the judgement of design as 'fine art' as opposed to 'applied art'. Design review does promote a holistic approach $(13 /+4)$, but this includes embracing subjective attitudes and tastes as a necessary part of the process. This discourse promotes design review as a process through which beauty is sought out in design, demanding buildings please visually and emotionally. 


\begin{abstract}
"The whole purpose of what we do in reviewing is to pass judgment on the aesthetic of a building or place, the review is not just about what the function is, it isn't even about the economics, our goal is to pass visual judgment, we want the best looking proposal, something that will be a noteworthy addition to the urban environment it is planned for" (Reviewer 3)
\end{abstract}

This discourse is self-aware that such an approach to the review process downplays the notion of accepted standards and regulations by which to review from $(16 /-4)(18 /-1)$, suggesting instead a process with high levels of institutional discretion and individual reviewer freedom (agency) $(31 /+1)$.

\title{
F. THE DEMOCRATIC PROCEDURALIST
}

\section{Explains $16 \%$ of the study variance.}

The distinguishing characteristics of this discourse are the clear claims that review operates under strict procedures and objective standards, rejecting the idea that subjectivity and personal taste play a significant role in the decision making process (17 / -4) $(10 /+1)$. Rather design review is based on strict procedures and objective accepted standards and criteria $(18 /+3)$ and the ability to represent public opinion and needs $(9 /$ +3). The Democratic Proceduralist agenda calls for greater statutory wright to be given to design review panels $(33 /+4)$. Such a move would provide review decisions legitimacy within the law, strengthening the ability of the process to make significant impacts upon design quality in the public interest. This democratic approach includes the desire to see all architects, regardless of stature, reputation, or ability, equally eligible to undergo review (34/-2). 


\section{G. THE CRITICAL FUNCTIONALIST}

Explains $17 \%$ of the study variance.

The distinguishing characteristics of this discourse are that the review process is about evaluating how well a design responds to people and communities $(7 /+4)$. Further examination of the responses defining this discourse showcase that this response to people is more concerned with how well a design functions $(18 /+2)$ rather than legitimising the public as an audience for architecture $(9 /-2)$, however design review can at times act as a bridge between the tastes of professionals and lay-people $(14 /+1)$. A significant distinguishing feature is the critical, and disillusioned, tone with which current design review is regarded, with disagreements and a lack of consensus commonplace between reviewers $(19 /+2)$ and certain reviewers sabotaging the process by attempting to pass as experts, and evaluate, issues outside their accepted expertise $(28 /+3)$.

\footnotetext{
"Consensus, you must be joking, if there are eight on a panel, the best you can hope for is seven different views, and perhaps three serious clashes of opinion. These are rarely resolved before the chair overrules, often without the panel members even being aware" (Reviewer 9).
}

\section{The Contested Nature of Design Review}

The discourses described above serve to identify four distinct priorities that different reviewers place on the process and purpose of design review. There is evidence within the findings that consensus can be found across the design reviewers involved, such as encouraging a holistic approach to design (Statement 13). This agreement on observing a holistic approach can actually account for the different priorities uncovered across 
design review and suggest differences of opinion and approach are not necessarily negatives, more of which this paper will discuss in its conclusions. The four priorities identified can be framed as 'Sustainable Solutions'; ‘ People/Public'; Function'; and 'Visual Aesthetics'.

\section{Sustainable Solutions}

The dominance of the 'post-political' condition (see Swyngedouw [2009]) wherein discourses such as sustainability are a taken for granted good, beyond disagreement, driven by neo-liberal ideology (Johnstone 2014), suggest that a system such as design review would place high value on the importance of sustainability in assessing the design. This is certainly true of The Objective Contextualist and The Critical Functionalist, where sustainability aspects of a proposed development are the primary focus of evaluation and objective evaluation. This focus provides the review process with evidence of objectivity and consequently transparency, considering the myriad of standards and criteria available for rating sustainability (see Nguyen and Altan [2011]), and supports the views of Stamps (2000) and Punter (2006) that contemporary review focuses on more measurable issues including sustainability. Yet this notion that design review has sustainability at its core is challenged, and indeed rejected, by The Beauty Hunter. Reviewers associated with this identified discourse argue the process does not engage closely with assessing sustainable solutions and responses in design proposals.

\section{People / Public}

The three discourses identified on the issue of defining design quality Discourses A, B, and C) introduced the idea that people, or the public, are key in the conceptualisation of 
design quality (see The Contextual Populist) and the importance of the wider population can also be distinguished in the discourses on design review process. The Democratic Proceduralist perceives that the review process is predominately about engaging with a designs impact on communities and public opinion. The panel must make efforts to act on behalf of, and represent, the public to ensure high quality that works in context and for the needs of local people. Whilst context was an area all reviewers agreed was vital, only The Democratic Proceduralist elevates design reviews role in legitimising the views of the public. The Beauty Hunter and The Critical Functionalist are particularly strong in their views that public opinion is not a concern for design review, rather it is about the skill and experience of the reviewer in evaluating design matters. The review process rarely has layperson representation, nor is there a clear mandate or mechanism to engage directly with the wider public suggesting reviewers placing high value on this are misguided. Yet the process remains part of a design control system that is administered on behalf of the State, and whilst reviewers are not publically elected figures, it is arguable that part of the role of the review process is to benefit the public in the policing or management of design quality. This attitude becomes problematic when considering research that has identified clear differences in how laypersons and design professionals perceive and articulate design quality (Devlin 1990; Hubbard 1996; Gillford et al 2000).

\section{Function}

How successfully a development functions within its intended usage is a question all four discourses agree is a vital question design review must be asking of proposed schemes. This perspective is most clearly articulated in The Critical Functionalist, wherein functionality is defined as the core evaluation area within the review process, 
and an area that review can have significant impact on improving as part of its recommendations and conclusions. How function is actually measured or evaluated is unclear however, with few accepted studies or standards providing agreed upon approaches or measurement techniques. Function can be argued to be not simply an objective variable. Standing as an obvious area of consensus amongst the design reviewers, alongside contextual appropriateness of design solutions, it can be considered valuable common ground within design review panels.

\section{Visual Aesthetics}

Much of the current design review literature places great stock in the shift from potentially subjective considerations to evaluating through more accepted objective measurements and standards, promoting a more transparent process (Design Council CABE 2013). Stamps (2000) supports this contemporary design review claim, arguing the original focus on visual aesthetics has been replaced with a concentration on new urban discourses such as sustainability. Whilst the four identified discourses in this research have supported this shift in many ways, including seeking out objective approaches and elevating sustainability as a core component of the process, they have also evidenced that this 'shift' has not eradicated a focus on aesthetics completely. The Beauty Hunter discourse provides evidence that certain design reviewers today still consider assessing visual design quality a priory, identifying design review as about 'fine arts', associated with beauty and emotion, rather than the more transparent and structured 'applied arts'. This attitude is further supported by The Beauty Hunter ascertaining that design review places significant emphasis on subjective appraisal, that the contemporary process remains discretionary and lacking in predictability with no defined rules from which to create or assess beauty. This perspective echoes the 
subjective aesthetic approach favoured by design review in the past, including the original forerunner, The Royal Fine Arts Commission. Current design review literature purposefully distances itself from this 'traditional' approach (CABE 2011; Design Council CABE 2013), due to the 'cloak of diplomacy and secrecy' (Punter 1984) that often surrounded its interventions. The Beauty Hunter discourse calls into question the claims of contemporary design review to be fully transparent and objective, and provides compelling evidence that traditional perceptions on how review operates and what is assess still exist and permeate the process today. This also calls into question the ability of design review panels to control and manage panel members, if the ability to deviate from core principles exists, as indicated by this research, how can design review respond? And should it?

\section{Conclusions}

The evidence provided by the above discourses regarding the process and purpose of design review, in particular (but not exclusively) The Beauty Hunter, points towards a mechanism that has no clearly defined mandate or evaluative approach. A picture has emerged of a design review process that is defined as much by contention amongst reviewer perceptions and approaches as by the areas of consensus, a viewpoint articulated best by the Critical Functionalist. Figure 2 illustrates the relationship between the designer reviewer discourses, with clear disconnects between certain perspectives.

Figure 2. Relationship between reviewer discourses on purpose and process of design review. 
The first Q-Sort conducted, considering the definition of design quality within design review, highlighted the, perhaps expected, complexity of design and its multiple aspects and considerations. Contemporary design review is at pains to move away from this complexity and confusion through a more measured approach that considers objective standards and agreed upon standards in a transparent and impartial way (Design Council CABE 2013), yet the second Q-Sort challenges this new agenda. If this new objective and transparent methodology does indeed exist it is, based on this research, not being fully embraced, or adhered too, by all reviewers. Rather what is presented in this paper is a review process that is populated with individual reviewers who define the review approach, and quality, in different ways. A key salient point evidenced in all the discourses is a general agreement that the design review process, as it currently stands, is open to abuse and misdirection (Statement 23). This is in part due to certain reviewers exercising high levels of agency in the process, shaping design review to fit their personal values and perceptions on conceptualising and evaluating design quality. When this occurs the risk is that reviewers attitudes and approaches come into conflict with one another, posing a series of critical questions about how these conflicts are resolved and how can review retain the level of transparency it attempts to promote.

It is important to state that the views and judgements of reviewer's within the process are not necessarily all accounted for in the final panel report and recommendations. The panel chair ultimately draws up the final report on behalf of the panel, and Carmona et al (2017) hint that the success of review relies heavily on the quality of this chairperson. What remains unclear in the process is how accurately this final report reflects the variety of discussion, evaluations, and vocalised perspectives of 
the gamut of design reviewers involved. A review of design review commissioned by Place Alliance, Urban Design London, and the Greater London Authority (Place Alliance 2018) concluded that secretive practices remain in the process, making many panels "patently not transparent or accessible" (p 91). What this research indicates is a process that is diverse in its membership, not only in terms of professional experience and profession, but also in the fundamental concerns of how they think about and appraise design quality within the confines of the review mechanism. An argument can be presented that such diversity and a broad spectrum of approaches and perceptions can actually benefit the process as disagreement and debate can often force individuals to both question and justify their own position more robustly and reflect more deeply on rationalising their decision-making. Yet it can become a significant concern if individuals fail to consider the views of others and pull in different directions, leaving those involved in the process with no clear understanding of what is being appraised on a proposal, and how.

The discourses identified in this paper point towards a contested design review mechanism, which at best can be described as being constantly negotiated between its members. Idealistic claims of transparency and objectivity do not sit easily with this contested vision of review and underplays the significant role of the agent (reviewer) in defining their own approach within the system. The contested nature of reviewers attitudes and perceptions to both quality and the review process discussed here serves to illuminate the influence these agents have on shaping the core aims and purpose of review.

Therefore to gain an accurate understanding of the design review process, and to tackle the unanswered questions posed by contemporary review (see Carmona [2016a]), this paper argues that reviewers themselves be central. The broad aim of design review 
may remain the evaluation of design to promote and improve quality within architecture and urban design, hinting at a shared corporate agenda, but reviewer discourses here reflect a deeper truth, that achieving this end is complex and conducted through various, at time contrasting and conflicting, approaches. Only through engaging with these reviewers can the process be made truly 'transparent'.

The nature of design and its multiple facets will always leave design review with its critics and open to claims of subjectivity and even bias in its evaluations. Yet gaining a deeper understanding of the way in which reviewers think and operate within the process can assist in developing more robust future approaches. It is clear that design review does lack a defined process, an agreed objective approach to evaluate from, and it offers its reviewers high levels of discretion and agency. Add a focus on design quality to this mix and it is a system that clearly struggles to be fully objective or transparent by its very nature. Perhaps the issue lies with the desire to be seen to be different from past incarnations, because if beauty really is in the eye of the design reviewer then design review can ill afford to change.

Design review must rather embrace the subjective alongside the objective and accept that its 'expert-led' approach means it will forever remain a contested mechanism, which perhaps it must be to truly reflect, and engage with, the contested field of design quality it works within. Others have called for increased transparency (Place Alliance 2018) and clarity of process (Urban Design London 2015), this does not have to be a rigid shift to purely objective appraisals, but can rather be a more honest and accessible process whereby review panels accept their naturally contested state more openly. This paper has highlighted not only contention, but also areas of consensus, potential areas of common thinking and understanding that could prove a useful starting point for discussions and initial appraisals, issues such as contextual 
responsiveness and materiality. By recognising these areas of agreement and commonality it may make it easier to also then recognise areas of disagreement. This would be a major step towards developing transparency in the process, and ensuring design review continues to play an active and positive role in the drive to increase and manage quality within the built environment both now and in the future.

\section{References}

Allmendinger, P. 2002. "Towards a Post-Positivist Typology of Planning Theory.” Planning Theory 1(1): 77-99.

Bishop, P. 2011. The Bishop Review, The Future of Design in the Built Environment. London: Design Council.

Brown, S.R., Durning, D.W. and Seldon, G. 1998. "Q-Methodology.” in Handbook of Research Methods in Public Administration, edited by Miller G.J and Whicker M.L., 599-638. New York: Marcel Dekker.

CABE 2002. Design Review: Guidance on How CABE Evaluates Quality in Architecture and Urban Design. London: CABE.

CABE 2006. Design Review: How CABE Evaluates Quality in Architecture and Urban Design. London: CABE.

CABE 2009. Design Review: Principles and Practice. London: CABE.

Carmona, M. 1998. "Design Control-Bridging the Professional Divide, Part 1: A New Framework." Journal of Urban Design 3(2): 175-200.

Carmona, M. 2009. “Good Design - It's the Law!” Town and Country Planning 78(2): 98-99.

Carmona, M. 2014. “The Place-Shaping Continuum: A Theory of Urban Design Process." Journal of Urban Design 19(1): 2-36.

Carmona, M. 2016a. “Design Review: Past, Present and Future”, August 2016. http://discovery.ucl.ac.uk/1544279/1/Carmona_51.pdf

Carmona, M. 2016b. "Design Governance: Theorizing an Urban Design Sub-field.” Journal of Urban Design 21(6): 705-730.

Carmona, M., De Magalhaes, C. and Edwards, M. 2002. "Stakeholder Views on Value and Urban Design.” Journal of Urban Design 7(2): 145-169. 
Carmona, M. and Sieh, L. 2004. Measuring Quality in Planning: Managing the Performance Process. Oxon: Spon Press.

Carmona, M., De Magalhaes, C., and Natarajan, L. 2017. Design Governance: The CABE Experiment. London: Routledge.

Case Scheer, B. 1994. “Introduction: The Debate on Design Review.” In Design Review: Challenging Urban Aesthetic Control, edited by B. C. Scheer and W. F. E. Preiser, 1-12. New York: Chapman and Hall.

Conway, H and Roenisch, R. 2005. Understanding Architecture: An Introduction To Architecture and Architectural History. London: Routledge.

Davies, H.W.E. 1980. “The Relevance of Development Control.” Town Planning Review 51: 5-17.

Dawson, E. and Higgins, M. 2009. "How Planning Authorities Can Improve Quality Through the Design Review Process: Lessons From Edinburgh.” Journal of Urban Design 14(1): 101-114.

DCAL 2006. Architecture and the Built Environment for Northern Ireland. Belfast: Department for Communities and Local Government.

DCLG 2012. National Planning Policy Framework. London: Department for Communities and Local Government, March 2012.

DCLG 2014. Guidance: Design. 6 March 2014. https://www.gov.uk/guidance/design

Delafons, J. 1994. “Democracy and Design.” In (Eds.) 13-19. Design Review:

Challenging Urban Aesthetic Control. edited by B. C. Scheer and W. F. E. Preiser, 13-19. New York: Chapman and Hall.

Design Council CABE 2013. Design Review: Principles and Practice. London: Design Council.

Devlin, K. 1990. “An Examination of Architectural Interpretation: Architects Versus Non Architects.” Journal of Architectural and Planning Research 7: 235-244.

Dear, M.J. and Moos, A.I. 1986. "Structuration Theory in Urban Analysis: 1. Theoretical Exegesis." Environment and Planning A 18: 231-252.

Dryzek, J. S. \& Berejikian, J. 1993. "Reconstructive democratic theory." American Political Science Review 8(1): 48-60.

DTLR 2000. By Design: Urban Design in the Planning System: Towards Better Practice. London: DTLR.

Ellis, G., Barry, J. and Robinson, C. 2007. "Many Ways to Say 'No', Different Ways to Say 'Yes': Applying Q-Methodology to Understand Public Acceptance of Wind 
Farm Proposals." Journal of Environmental Planning and Management 20(4): 517-551.

Farrell, T. 2014. The Farrell Review of Architecture + the Built Environment, Our Future in Place. London. http://www.farrellreview.co.uk/download

Gilford, R., Hine, D.W., Muller-Clemm, W. and Shaw, K.T. 2000. "Decoding Modern Architecture: A Lens Model Approach for Understanding the Aesthetic Differences of Architects and Laypersons." Environment and Behaviour 32: 163-187.

Hansen, B. 2006. The National Economy. Westport, CT: Greenwood Press.

Hassell 2011. Design Review Research. Prepared for Green Building Council of Australia, August 2011. Melbourne: Hassell Limited.

Higgins, M. and Karski A. 2000. "The Built Environment and Design.” In Introduction to Planning Practice, edited by P. Allmendinger, A. Prior and J. Raemaekers. Chichester: Wiley and Sons.

Hinshaw, M.L. 1995. "Design Review." Planning Advisory Service Report Number 454, Chicago: American Planning Association.

Hopkirk, E. 2012. "Design Council CABE Appoints new Director." 19 January 2012. https://www.bdonline.co.uk/design-council-cabe-appoints-newdirector/5030745.article

House of Lords 2016. Building Better Places, House of Lords Select Committee on National Policy for the Built Environment. London: House of Lords.

Hubbard, P. 1996. "Conflicting Interpretations of Architecture: An Empirical Investigation." Journal of Environmental Psychology 16: 75-92.

Johnstone, P. 2014. "Planning Reform, Rescaling, and the Construction of the Postpolitical: The Case of the Planning Act 2008 and Nuclear Power Consultation in the UK." Environment and Planning C: Government and Policy 32(4): 697-713

Lock, D. 2009. "Rules for the Design Police.” Town \& Country Planning, July / August: 308-309.

McKeown, B. and Thomas, D. 1988. Q-Methodology. London: Sage.

Nguyen, B. K. and Altan, H. 2011. "Comparative Review of Five Sustainability Rating Systems." Procedia Engineering 21: 376-386.

Onaran, K.S. and Sancur, F.H. 1998. "Design Review in Small Communities." Environment and Planning B: Planning and Design 25: 539-557. 
Place Alliance 2018. Reviewing Design Review in London. London. https://indd.adobe.com/view/6b092a16-9991-4abf-a4ee-9da8719afec5

Punter, J. 1984. “A History of Aesthetic Control 1: The Control of External Appearance of Development in England and Wales 1909-1947." Working Papers in Land Management and Development, No.2. University of Reading: UK.

Punter, J. 1999. "Improving the Instruments, Processes and Products of Aesthetic Control in Europe." Urban Design International 4(1+2): 79-99.

Punter, J. 2006. “The Planning System and the Delivery of Design Quality.” In Urban Design Futures, edited by M. Moor and J. Rowland, 50-56. London: Routledge.

Punter, J. 2010. “Centenary Paper - Planning and Good Design: Indivisible or Invisible? A Century of Design Regulation in English Town and Country Planning.” Town Planning Review 81(4): 343-380.

Punter, J. and Carmona, M. 1997. The Design Dimension of Planning: Theory, Policy and Best Practice. London: Spon.

Rönn, M. 2011. "Quality in Architecture and Urban Design - A Disputed Concept." Design Research Journal 2(10): 46-54.

Schiffman, I. 1989. Alternate Techniques for Managing Growth. Berkeley: University of California, Berkeley.

Schumacher, A. 2011. Is Architectural Quality Ineffable? Contribution to RIBA futures debate, Business Design Centre, London.

SE, (Scottish Executive) 2005. SPP20: The Role of Architecture and Design Scotland. Edinburgh: Scottish Executive Development Department.

Stamps, A.E. 2000. Psychology and the Aesthetics of the Built Environment. Massachusetts: Kluwer Academic Publishers.

Swyngedouw, E. 2009. “The Antinomies of the Postpolitical City: In Search of a Democratic Politics of Environmental Production.” International Journal of Urban and Regional Research 33: 601-620.

TfL (Transport for London) 2013. Design Review: 2013 Programme Report. http://www.urbandesignlondon.com/wordpress/wp-content/uploads/DesignReview-Report-2012-13-EXTERNAL-short-draft.pdf

Urban Design London 2015. UDL's Design Review Survey Report January 2015. http://www.urbandesignlondon.com/wordpress/wp-content/uploads/UDLsDesign-Review-Survey-2014-2-2.pdf 
Van Exel, N.J.A. and de Graaf, G. 2005. Q Methodology: A Sneak Preview. [Available from http://www.jobvanexel.nl]

\section{from htp:/ www jobvanexel.nt]}

10

11

12

13

14

15

16

17

18

19

20

21

22

23

24

25

26

27

28

29

30

31

32

33

34

35

36

37

38

39

40

41

42

43

44

45

46

47

48

49

50

51

52

53

54

55

56

57

58

59

60

url: http://mc.manuscriptcentral.com/cjud 
(1) Active and retired design reviewers from the National Design Review Panel for Northern Ireland (MAG) identified and subject of sixteen semi-structured interviews.

(2) Transcriptions of the interviews reviewed by two researchers, identifying the significant statements made. A total of 577 initial statements selected and allocated to a matrix based on Dryzek and Berejikan (1993). Statements separated into categories (a) design quality; (b) design review process, and a final list of 23 statements (a) and 34 statements (b) were selected using the matrix to ensure at least one included from distinct perspectives on the topics.

(3) The next stage of the research was conducted by active and retired reviewers from the National Design Review Panel for Scotland (A+DS) (24 reviewers). This involved sorting the statements (on both categories - see Step 2) according to a ranking scale in quasi-normal distribution from 'most agreement' to 'most disagreement'. With all Q-Sorts, participants are forced to limit the number of statements they allocate to each ranking. This has the effect of forcing relative judgments on those statements at the extreme (see example ranking format, Figure 1), which facilitates more subtle understandings of the subjectivities applied (Ellis et al 2007). As part of this process participants are asked to self-identify their position, with interviews conducted to further explore the significance of their rankings. The end result of ranked statements is referred to as a Q-Sort.

(4) The Q-sorts were then evaluated using PQMethod software which using statistical correlation and factor analysis identifies clusters of participants (discourses) who sorted statements in a similar way.

(5) The statistical analysis is then interpreted by the researcher, using the rankings and the accompanying interviews conducted with participants. The result is a profile of each discourse, characterised by allocating each a distinct title. 


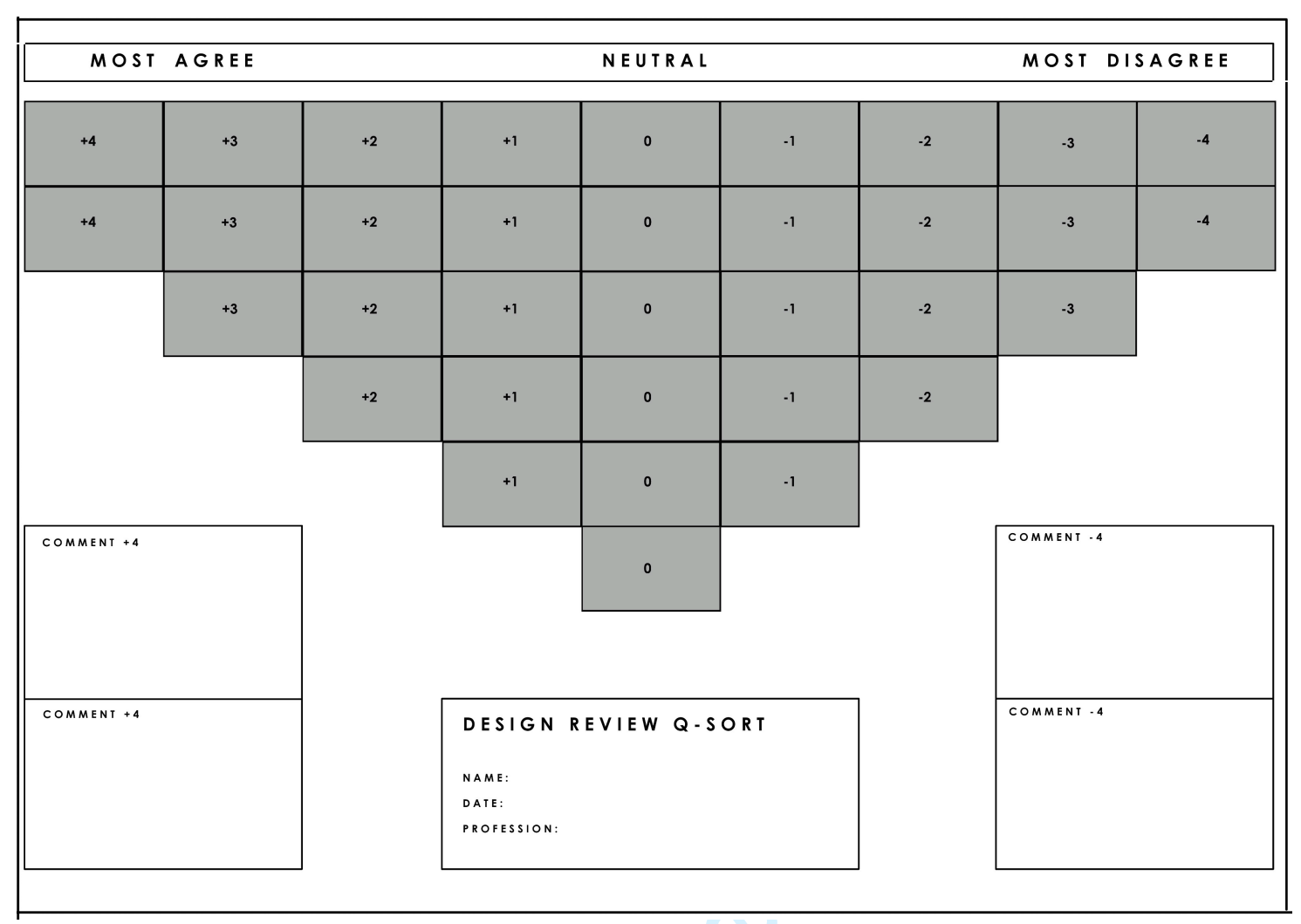




\begin{tabular}{|c|c|c|c|c|}
\hline \multirow[b]{2}{*}{ No. } & \multirow[b]{2}{*}{ STATEMENT } & \multicolumn{3}{|c|}{ DISCOURSES } \\
\hline & & $\mathbf{A}$ & $\mathbf{B}$ & $\mathbf{C}$ \\
\hline 1 & $\begin{array}{l}\text { Quality is about good materials, not necessarily expensive materials, but how you } \\
\text { combine them. }\end{array}$ & 3 & 2 & 0 \\
\hline 2 & Quality is how well a building works in terms of its function. & 3 & 1 & 1 \\
\hline 3 & Quality in architecture is something striking, magical, and breath-taking. & 2 & -1 & 0 \\
\hline 4 & Quality is a matter of objective standards that everyone can appreciate & 0 & -2 & -1 \\
\hline 5 & Quality comes from aesthetics that is what makes a building special. & -1 & -2 & -2 \\
\hline 6 & Quality is beauty, and beauty is in the eye of the beholder. & -3 & -1 & 0 \\
\hline 7 & $\begin{array}{l}\text { Quality in architecture is achieved through creating humane living environments and } \\
\text { democratic spaces. }\end{array}$ & 1 & 0 & 1 \\
\hline 8 & Quality is architecture that is enjoyed and acclaimed by the public. & -2 & -2 & 2 \\
\hline 9 & Quality in architecture is derived from a projects level of financial muscle. & -3 & 0 & -3 \\
\hline 10 & Taste plays no role in quality within architecture. & 0 & -1 & -3 \\
\hline 11 & $\begin{array}{l}\text { Whilst aesthetics play a role in achieving quality architecture, its subjective nature } \\
\text { means it should be avoided in evaluations. }\end{array}$ & 0 & -3 & -2 \\
\hline 12 & Quality fully depends on the skill of the architect. & -2 & 3 & 1 \\
\hline 13 & $\begin{array}{l}\text { There is a balance between personal taste and objectivity in recognising design } \\
\text { quality. }\end{array}$ & 2 & 1 & 2 \\
\hline 14 & Quality in architecture is about simplicity in design approach. & 0 & 0 & 3 \\
\hline 15 & Quality architecture is buildings at one with nature, growing out of the ground. & -2 & -3 & -1 \\
\hline 16 & Quality is contingent on sustainability; you cannot have one without the other. & 2 & -1 & 0 \\
\hline 17 & Quality architecture has to be driven by enlightened clients. & 1 & 2 & 0 \\
\hline 18 & $\begin{array}{l}\text { Quality comes from architects willing to take risks and work harder for the realisation } \\
\text { of their ideas. }\end{array}$ & 0 & 2 & 2 \\
\hline 19 & The only real test of architectural quality is time. & -1 & 1 & -2 \\
\hline 20 & $\begin{array}{l}\text { Aesthetics is a narrow reading of quality. It is about a combination of sensory } \\
\text { experiences. }\end{array}$ & 1 & 3 & 1 \\
\hline 21 & Quality appears in the relationship between the building and its landscape (context). & 1 & 1 & 3 \\
\hline 22 & Quality can only come about in architecture when the architect engages the public. & -1 & 0 & -1 \\
\hline
\end{tabular}




\begin{tabular}{|c|c|c|c|c|c|}
\hline \multirow[b]{2}{*}{ No } & \multirow[b]{2}{*}{ STATEMENT } & \multicolumn{4}{|c|}{ DISCOURCES } \\
\hline & & $\mathbf{D}$ & $\mathbf{E}$ & $\mathbf{F}$ & G \\
\hline 1 & $\begin{array}{l}\text { Design review is not about critical appraisal; it is about trying to aid designers in their } \\
\text { relationship with their clients. }\end{array}$ & -3 & -3 & 1 & 1 \\
\hline 2 & There is an inherent subjectivity that cannot be avoided in design review. & 1 & 1 & 2 & 2 \\
\hline 3 & Design review looks at the environments and the context, never the aesthetic of a building. & -4 & -3 & -1 & -1 \\
\hline 4 & $\begin{array}{l}\text { The purpose of design review is about visual aesthetics, it is concerned with fine arts, not } \\
\text { applied arts. }\end{array}$ & -1 & 4 & -1 & -4 \\
\hline 5 & $\begin{array}{l}\text { The fundamental question for design review is the issue of power, who judge's and whose } \\
\text { tastes matter? }\end{array}$ & -4 & -3 & -2 & -1 \\
\hline 6 & Design review is reluctant to acknowledge that there are no rules to create beauty. & 0 & -4 & 0 & 0 \\
\hline 7 & Design review is about buildings relationships with people and their lives. & 3 & 3 & 3 & 4 \\
\hline 8 & The basic criterion for design review is harmony with existing structures and terrain. & 3 & -2 & 0 & 3 \\
\hline 9 & Design review is about recognising the public as a legitimate audience for architecture. & 1 & -2 & 3 & -2 \\
\hline 10 & Taste does not enter into design review. & -2 & -1 & 1 & -3 \\
\hline 11 & The role of design review is to help with procurement. & 0 & -2 & -3 & -2 \\
\hline 12 & Design review is about the demand for sustainable solutions. & 4 & -1 & 2 & 3 \\
\hline 13 & Design reviews aim is to encourage a holistic approach to design. & 4 & 4 & 4 & 3 \\
\hline 14 & $\begin{array}{l}\text { The main aim of design review is to bridge the gap between lay and professional tastes in } \\
\text { architecture. }\end{array}$ & 0 & -4 & -2 & 1 \\
\hline 15 & $\begin{array}{l}\text { During a review you will often not say what you really think, it is a person-to-person } \\
\text { courtesy. }\end{array}$ & 0 & -1 & -3 & -2 \\
\hline 16 & Applicants to design review are very supportive and grateful for the process. & 2 & 2 & 0 & 1 \\
\hline 17 & Taste is a major issue in design review, it is inextricably linked with what review does. & 0 & -2 & -4 & 0 \\
\hline 18 & $\begin{array}{l}\text { Design review is about appraisal of architecture using principles such as those devised by } \\
\text { Vitruvius, including commodity, firmness and delight. }\end{array}$ & 3 & -1 & 3 & -2 \\
\hline 19 & Design review throws up many differences of opinion. & -1 & 0 & 1 & 2 \\
\hline 20 & Design review is not open to a level of discretionary judgement. & -1 & -1 & -1 & 1 \\
\hline 21 & There is never disagreement on a panel, there is always consensus. & -1 & 0 & -1 & -4 \\
\hline 22 & Everyone reviews in his or her own way; there is no right or wrong answer. & 1 & 0 & 0 & 2 \\
\hline 23 & Design review has potential for abuse and misdirection. & 1 & 3 & 2 & -1 \\
\hline 24 & Design review is overly cosmetic and limits designer creativity. & -3 & 0 & -4 & -3 \\
\hline 25 & Often architects find design review cumbersome, time-consuming and ineffective. & -2 & 0 & 2 & 0 \\
\hline 26 & Design review panels never agree what they think quality is. & -3 & 3 & -3 & -1 \\
\hline 27 & $\begin{array}{l}\text { Review panels have their hands tied as they are committed to what they have reviewed and } \\
\text { accepted previously. Consistency is crucial. }\end{array}$ & -2 & 0 & 1 & 0 \\
\hline 28 & Some panel members make the mistake of pretending to be experts in everything. & -1 & 2 & 0 & 3 \\
\hline 29 & $\begin{array}{l}\text { There is often excessive discretion, vagueness and a lack of predictability in the design } \\
\text { review process. }\end{array}$ & 0 & 2 & -2 & 1 \\
\hline
\end{tabular}




\begin{tabular}{|c|c|c|c|c|c|}
\hline 30 & With open and vague criteria personal judgements do play some role in design review. & 2 & 1 & 1 & 2 \\
\hline 31 & $\begin{array}{l}\text { Design review has freedom at its core, reliable principles from which to review are } \\
\text { suspicious by their absence. }\end{array}$ & -2 & 1 & -1 & -1 \\
\hline 32 & Design review is about promoting the orderly and harmonious growth of a community. & 2 & 1 & 0 & 0 \\
\hline 33 & Design review boards need statutory weight, why bother if it has no teeth. & 1 & 2 & 4 & 0 \\
\hline 34 & $\begin{array}{l}\text { Design review is not about controlling good architects, but controlling mediocre architects } \\
\text { or projects without architects. }\end{array}$ & 2 & 1 & -2 & -3 \\
\hline
\end{tabular}




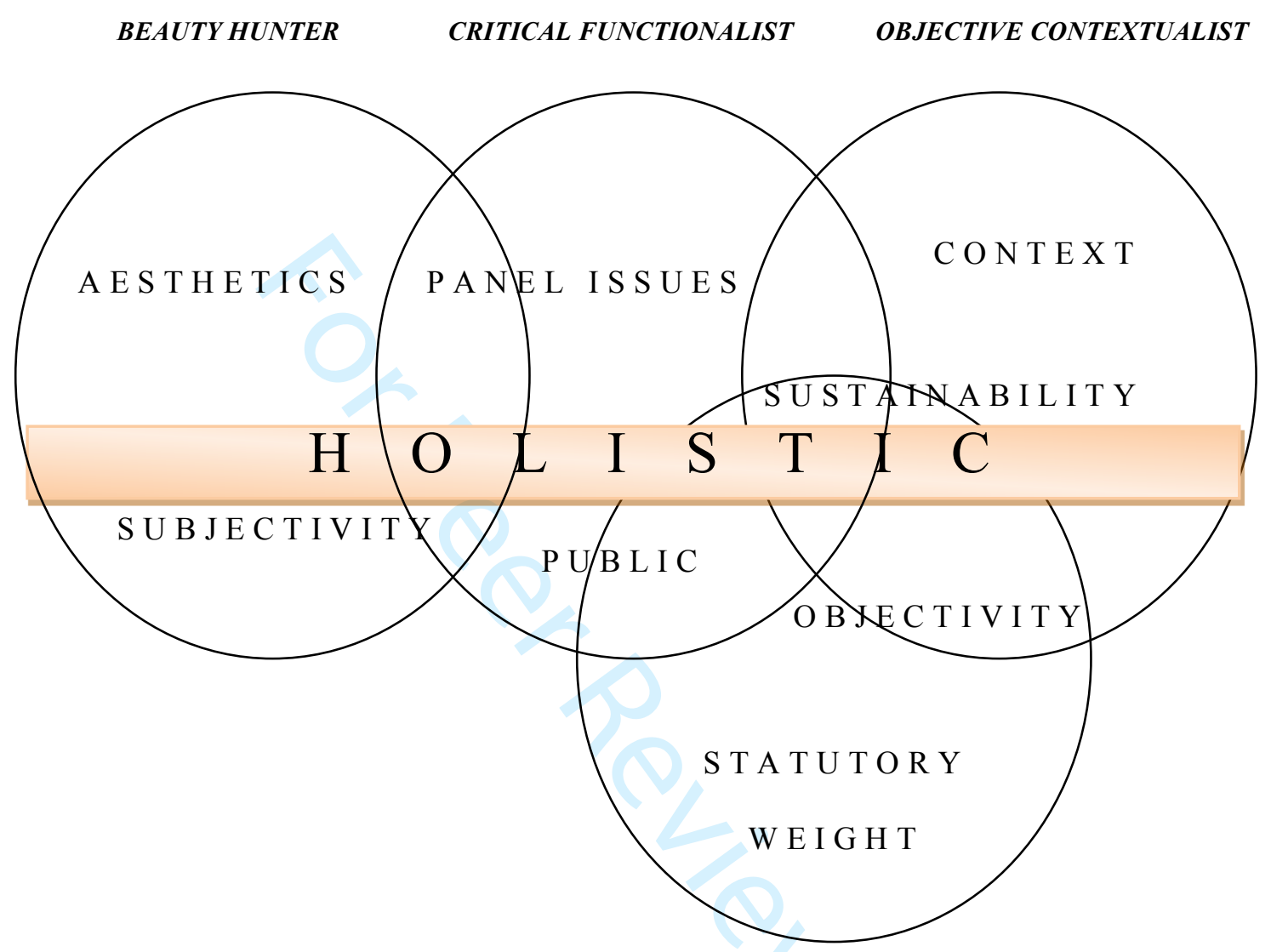

DEMOCRATIC PROCEDURALIST 